\title{
The sedimentological changes caused by human impact at the artificial channel of Medjerda-River (Coastal zone of Medjerda, Tunisia)
}

\author{
Thouraya Benmoussa $^{1}$, Oula Amrouni ${ }^{2}$, Laurent Dezileau ${ }^{3}$, Gil Mahé ${ }^{4}$, and Saâdi Abdeljaouad ${ }^{1}$ \\ ${ }^{1}$ University of Tunis El-Manar, Faculty of Science, \\ Laboratory of Mineral Resource and Environment, Tunis, Tunisia \\ ${ }^{2}$ National Institute of Marine Sciences and Technologies, \\ Laboratory of Marine Environment, Tunis, Tunisia \\ ${ }^{3}$ University of Montpellier II, HDR-Géosciences, Montpellier, France \\ ${ }^{4}$ UMR HydroSciences Montpellier/IRD, Montpellier, France
}

Correspondence: Thouraya Benmoussa (benmoussa_thouraya@yahoo.fr)

Received: 13 June 2017 - Revised: 6 December 2017 - Accepted: 22 December 2017 - Published: 16 April 2018

\begin{abstract}
Recent sedimentary and morphological changes at the new mouth of Medjerda-River (Gulf of Tunis) are investigated using a multiproxy approach of sediment cores complited by ${ }^{210} \mathrm{Pbex}$ and ${ }^{137} \mathrm{Cs}$ method dating. The subject of the study is to focus on surveying the sedimentary evolution of Medjerda-Raoued Delta caused by the human intervention in the management of the main tributaries of the Medjerda-River (artificial channel of Henchir Tobias). Sediment cores (CEM-1 and CEM-3) were subjected to both multiproxy approaches (Grain size, geochemical analysis and dating radiometric ${ }^{210} \mathrm{Pbex}$ and ${ }^{137} \mathrm{Cs}$ ). The sedimentological analysis of the new deltaic deposits shows a progradation sequence with the silt and clay deposits on the historic sandy substratum. The mean grain size evolution on the old beach profile shows a decreasing trend from backshore (CEM-3) to nearshore (CEM-1). The geochemical results show varying concentrations of chemical elements such as Fe, K, $\mathrm{Rb}, \mathrm{Nb}, \mathrm{Cr}, \mathrm{Ti}, \mathrm{Ba}, \mathrm{Ca}, \mathrm{Sr}, \mathrm{Zr}, \mathrm{V}$, and potentially toxic metal trace elements such as $\mathrm{Pb}, \mathrm{Zn}$ and the As. The Principal component Analysis (PCA) applied in the geochemical elements evolution confirms the marine origin of the sand deposits in the basic layers of the two cores. The chronological method $\left({ }^{210} \mathrm{Pbex}\right.$ and $\left.{ }^{137} \mathrm{Cs}\right)$ affirms that the first fluvial deposits were set up only after 1950. The sedimentological and geochemical result confirm the actual unless of coarser fluvial supplies under the human activities leading the negative coastal sediment balance and the shoreline retreat as well.
\end{abstract}

\section{Introduction}

The sediment budget of the coastal area is subject to several factors. The natural one is related to the sand supply sources and the eolian/hydrodynamics regime. The human factor represents an important element on the equilibrium of the coastal budget. Considering the coastline in its three dimensions, some authors have concentrated on the geomorphological balances of sedimentary flows, cell per cell (Suanez and Sabatier, 1999; Amrouni et al., 2014). The scientific community has also raised the question of the natural and human factors impacton the coastal sandy beach supplies (Flemming and Hansom, 2011).

The study of coastal environments linked to different global rivers is all the more important as they can be considered as markers of the evolution of sedimentary contributions in marines environments in relation to climatic as well as human variations (Milliman and Meade, 1983; Syvitski and Kettner, 2011; Kotti et al., 2015). The evolution of the nearshore sedimentary distributionis also related to the variability of hydrodynamic forcing and sediment availability in coastal areas (Perillo, 1995). The study area constitutes the coastal alluvial plain of the Medjerda River, the western bay 


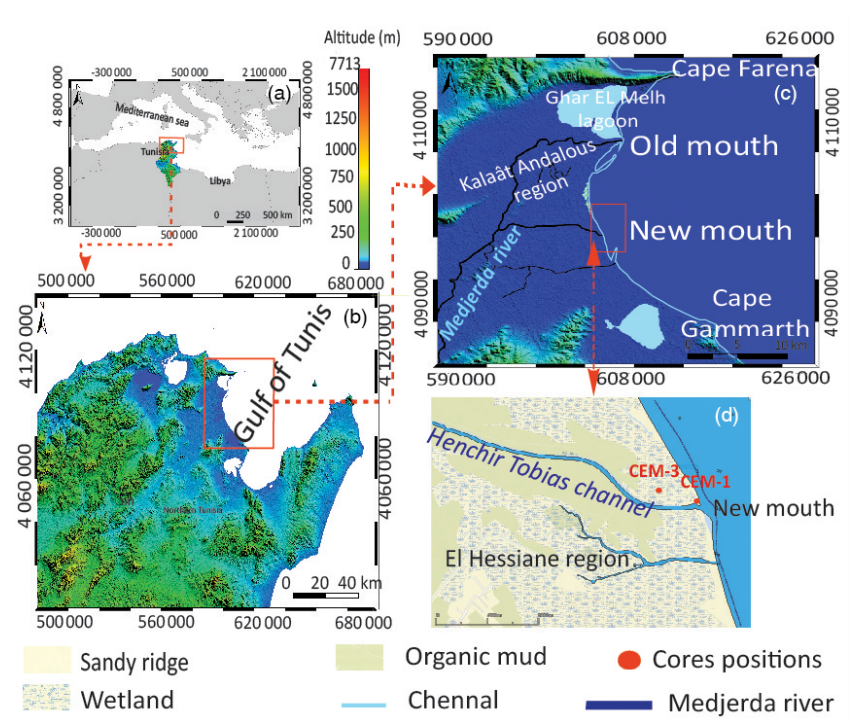

Figure 1. Map of study area location and cores sampling, deltaic coastal plain of the new mouth of Medjerda river, gulf of Tunis, NE of Tunisia. (a) Position of Tunisia in the Mediterranean Sea; (b) Northern-East of Tunisia; (c) topographic map of the gulf of Tunis, (d) the Sediment cores positions at the new mouth of Medjerda River.

of the gulf of Tunis. It is an estuarine coast, which receives the majority inputs feeding from the terrestrial hinterland (Oueslati et al., 2004). The anthropogenic activity mainly influencing the evolution of the northern coast sediment distribution of the Gulf (Saïdi, 2013; Saïdi et al., 2014).

The subject of this study is to describe the spatio-temporal impact of the management of the river flume on the sedimentological characteristics at coastal deltaic artificial channel of Medjerda River. We use a combined approach of sediment cores analysis and the ${ }^{210} \mathrm{~Pb}$ and ${ }^{137} \mathrm{Cs}$ method dating to follow the creation and development of the new delta of Medjerda River (anthropogenically modified since 1972) (Soussi, 1988).

\section{Study area}

The study area, the Medjerda coast is located in the western bay of the gulf of Tunis between $37^{\circ} 10^{\prime} \mathrm{N}-10^{\circ} 16^{\prime} \mathrm{E}$ (Cape Farina) and $37^{\circ} 55^{\prime} \mathrm{N}-10^{\circ} 18^{\prime} \mathrm{E}$ (Cape Gammarth). The coastis characterized by three main sedimentary systems with three morphological entities: Lagoons of Kalaât El Andalous, Delta of Medjerda and the foredunes of Raoued in the El Hessiane areas (Fig. 1).

\section{Material and methods}

The methodology was based on sedimentological investigation completed by geochemical analysis on the new mouth of Medjerda River. Two short sedimentary cores CEM-1 and

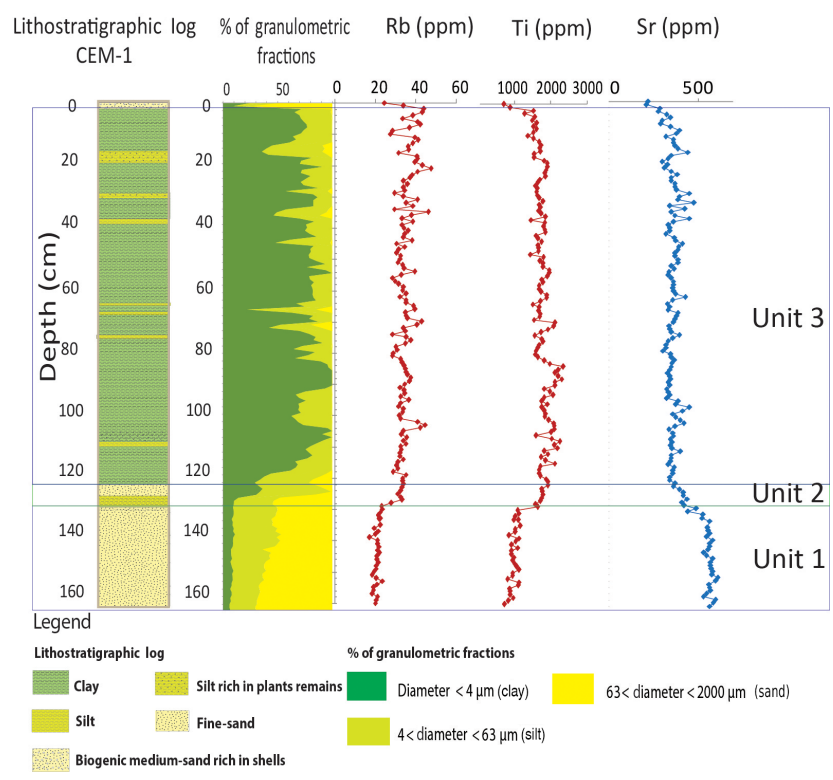

Figure 2. Grain size and geochemical elements evolution of deltaic plain of new mouth of Medjerda River (CEM-1).

CEM-3 were collected from the Medjerda delta in the northeast of the Gulf of Tunis (Fig. 1c and d). The sampling protocol adopted consists of collecting $1.68 \mathrm{~m}$ and $45 \mathrm{~cm}$, respectively for the two cores of deep sediment, in order to reconstitute a fine sedimentary evolution on the new mouth of Medjerda River evolution. A high resolution multi-proxy study was undertaken on the cores in the UM, HDR-laboratory, France. The granulometric analysis was carried out using a Beckman Coulter () LS 13 320. The geochemical analysis was conducted on the sedimentary material using the X-ray Fluorescence.The Principal Component Analysis (PCA) was carried out under the XLSAT-2016 software. Based on ${ }^{210} \mathrm{~Pb}$ and ${ }^{137} \mathrm{Cs}$ by Gamma spectrometry in order to establish a chronology on the sedimentary evolution of the new delta of Medjerda-River during the last century.

\section{Results and discussion}

\subsection{Grain size and geochemical evolution of sediment cores}

The high-resolution $(1 \mathrm{~cm})$ grain size analysis of the cores shows a spatial variability. The CEM- 1 core shows three distinctive sedimentary units (Fig. 2). The layer of fine sand (D50 $=98 \mu \mathrm{m}$ ), is surmounted by mixture of fine sand and silt laminates (Unit 2). But, the upper layer (Unit 3) is composed by clay (Unit 3 ). The CEM-3 core reveals the same sedimentary units (Unit 1, Unit 2 and Unit 3) (Fig. 3).

The geochemical results show varying concentrations of chemical elements such as $\mathrm{Fe}, \mathrm{K}, \mathrm{Rb}, \mathrm{Nb}, \mathrm{Cr}, \mathrm{Ti}, \mathrm{Ca}, \mathrm{Sr}, \mathrm{Zr}$, $\mathrm{V}$, and potentially toxic metal trace elements such as $\mathrm{Pb}, \mathrm{Zn}$ in the sedimentary cores. The evolution of the contents of 


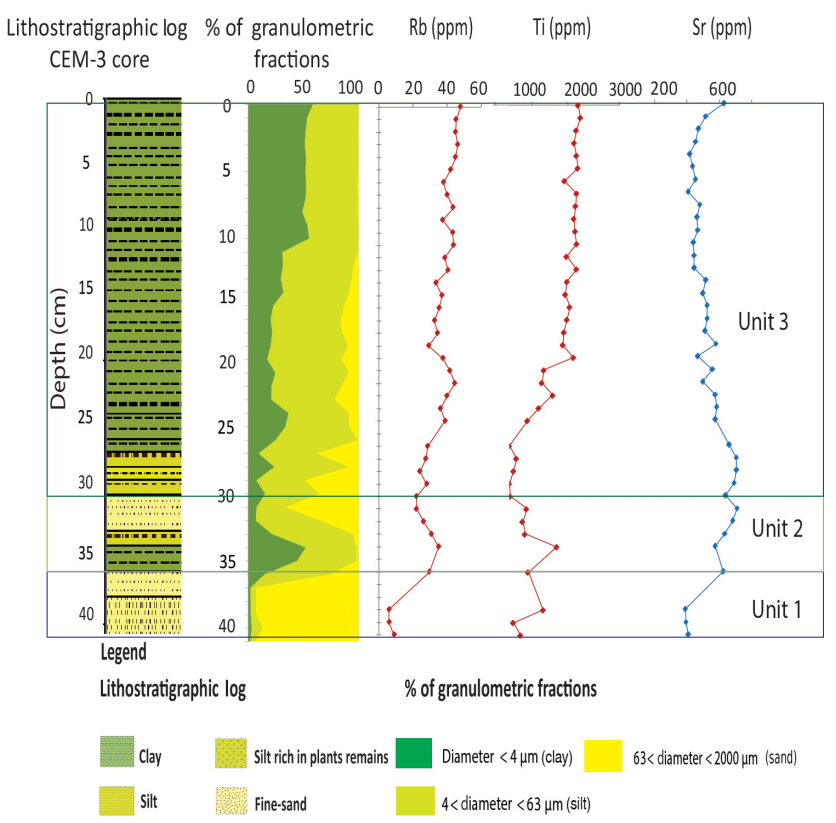

Figure 3. Grain size and geochemical elements evolution of alluvial plain of new mouth of Medjerda River.

chemical elements in the sedimentary column reveals a good correlation with the grain size analysis. The marine tracers $(\mathrm{Ca}, \mathrm{Sr})$ show a significant decreasing concentration in the clay layers compared to their rate in the sandy one. While to the rate in terrigenous elements is higher in the fine sediments (clay and silt) (Figs. 2 and 3).

The Unit 1 of CEM- 1 formed by fine-sand (D50 $=98 \mu \mathrm{m}$ ). But the Unit 1 of CEM-3 composed by medium-sand $(\mathrm{D} 50=228 \mu \mathrm{m})$. The mean grain size (D50) evolution on the historical beach profile (before the alluvial deposits processes) shows a decreasing trend from the backshore (CEM3) to the nearshore (CEM-1) (Fig. 4).

\subsection{Correlation of geochemical elements}

The Principal Component Analysis (PCA) of the geochemical elements shows the presence of 3 poles (Fig. 5): a pole of terrigenous elements $(\mathrm{Fe}, \mathrm{K}, \mathrm{V}, \mathrm{Rb}, \mathrm{Cr}$, Ti), a pole of marine elements $(\mathrm{Ca}, \mathrm{Sr})$ and a pole of the pollutant minerals $(\mathrm{Zn}$, $\mathrm{Pb}$ and $\mathrm{As})$. A good correlation established between the elements present in the same pole. An anti-correlation observed between the first (fluvial elements) and second pole (Marine elements).

The grain size and geochemical analysis of the sediment cores shows that the finest detrital deposits (silt and clay) manifested the progradation of a new delta at the new mouth of the artificial channel. The grain size correlation established from the backshore to the nearshore shows that the historic beach was behind the present shoreline and the nearshore area was located on the current beach. It is a delta progradation on the old sandy beach. The retained fluvial dis-

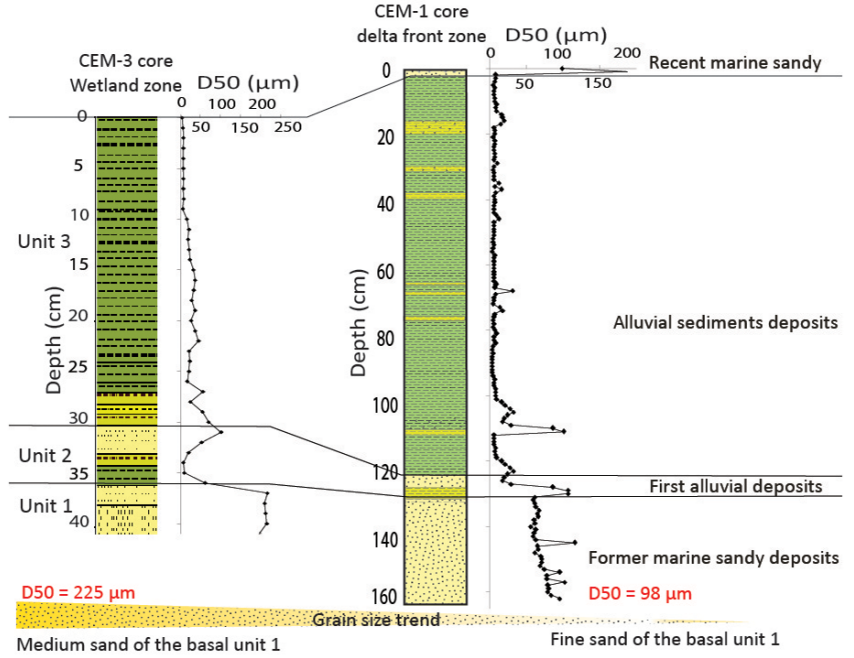

Figure 4. The mean grain size evolution of the old sandy deposits from the wetland (CEM-3) to the delta front (CEM-1) of the Medjerda River.

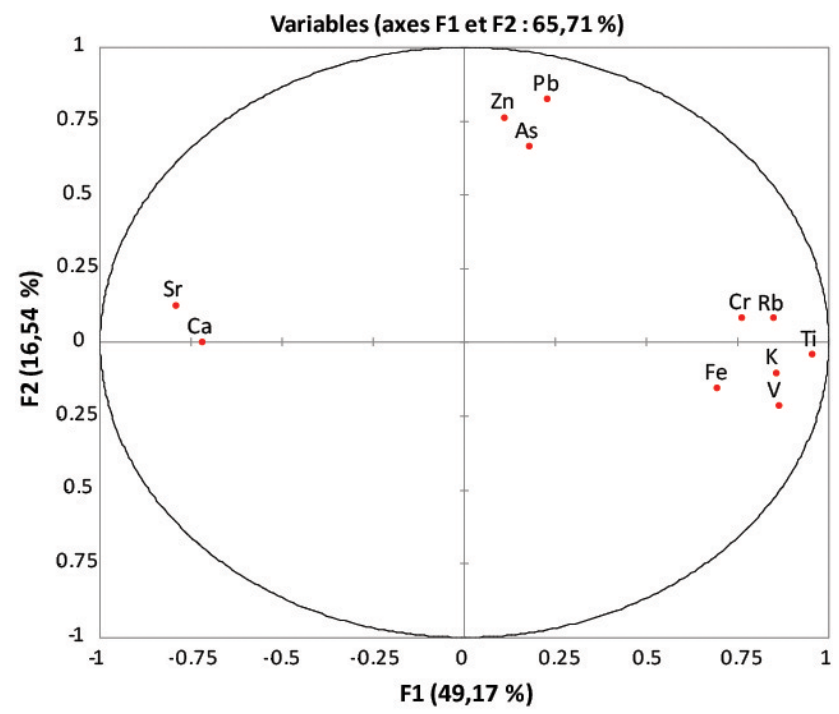

PCA of CEM-1 core: in the delta front zone of Medjerda river.

Figure 5. Principal Component Analysis of geochemical elements of the CEM-1 core sediments.

charge by the dam construction decreases the coarser fraction delta front toward silt to clay deposit.

\subsection{Historical evolution of the new delta of the Medjerda}

The ${ }^{210} \mathrm{~Pb} /{ }^{137} \mathrm{Cs}$ method dating shows that a new delta has been developed at the new mouth of the Medjerda since 1950. The Cesium 137 is an artificial radioactive element produced by the atmospheric nuclear tests. It is foundin the atmospheric environment from the years 50. The contents relatively important of cesium-137 measured in the units

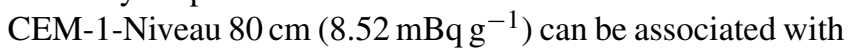




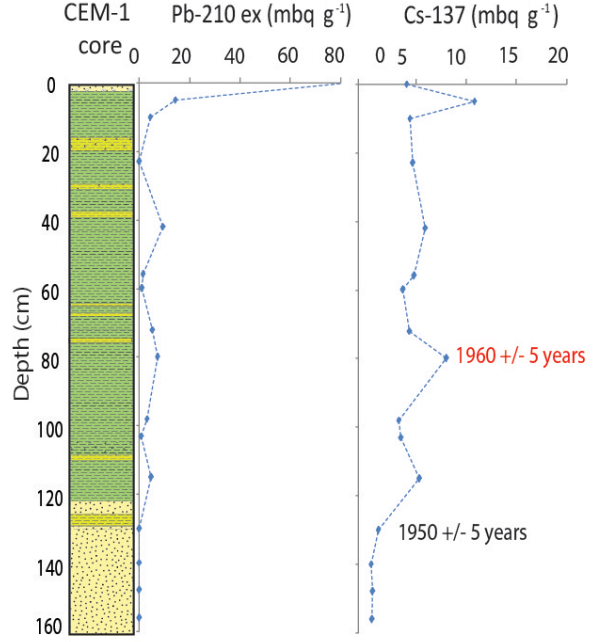

Figure 6. Geochronologyof sedimentary deposits at the new mouth of the Medjerda River.

the maximal production of cesium-137 atmospheric in the middle of 1960s (Fig. 6). However, The variability of content ${ }^{137} \mathrm{Cs}$, along the CEM-1 core is the result of the mobilisation of this element especially in the marine and coastal environments, which does not allow to fix easily the real peak of maximum of nuclear broadcast (emission, issue) of 1963 (Dezileau et al., 2014). As a result, the relatively high cesium-137 levels measured in the CEM-1-Level $80 \mathrm{~cm}$ units $\left(8.52 \mathrm{mBq} \mathrm{g}^{-1}\right)$ can be associated with the maximum production of atmospheric cesium-137 in the mid-1960s. The first peak which appeared at the base of the CEM-1 core at $-115 \mathrm{~cm}$ results from the appearance of ${ }^{137} \mathrm{Cs}$ contained in aged layers of the appearance of this element in the atmosphere (before 1950).

\section{Conclusions}

The result shows a relatively rapid deltaic plain progradation $\left(1.53 \mathrm{~cm} \mathrm{yr}^{-1}\right)$ with a fluvial dominance marked by silt and clay deposits rich in terrigenous chemical elements from the year 1950. This sedimentary evolution of the new delta is manifested by the filling of the old mouth since 1973 flood. The winnowing of finest fraction (clay and silt) provided during the flood event on the delta front, by the active wave current ledto the preferential spatial grain size distribution toward the northern behavior coast.

The dominance of clay deposits more than coarser fraction result to the impact of the dam construction of several dams. Only the finer grain size fractions can feed the coast. The actual sediment balance of the gulf of Tunis coast shows a shoreline retreat under the coarser sediment deficit blocked by upstream dam construction.
Data availability. No data sets were used in this article.

Competing interests. The authors declare that they have no conflict of interest.

Special issue statement. This article is part of the special issue "Water quality and sediment transport issues in surface water". It is a result of the IAHS Scientific Assembly 2017, Port Elizabeth, South Africa, 10-14 July 2017.

Acknowledgements. The present study was investigated under the bilateral Tunisan-French project Utique-CMCURYSCMED16G1005 (2016-2018).

Edited by: Hafzullah Aksoy

Reviewed by: two anonymous referees

\section{References}

Amrouni, O., Hermassi, T., AbdelJaouad, S., and Messaoudi, S.: Contribution of Grain-size Trend to Sediment of a Microtidal Beach. Case of the Gulf of Tunis Bay (Cape Ferina-Cape Gammarth, Tunisia), Research Journal of Environmental Sciences, 8, 161-177, https://doi.org/10.3923/rjes.2014.161.177, 2014.

Dezileau, L., Terrier, B., Berger, J. F., Blanchemanche, P., Latapie, A., Freydier, R., Paquier, A., Lang, M., and Delgado, J. L.: Reconstitution des crues extrêmes du Gardon à partir d'une analyse paléohydrologique, Houille Blanche, EDP Sciences, 4, 44-52, https://doi.org/10.1051/lhb/2014037, 2014.

Flemming, B. W. and Hansom, J. D.: Estuarine and Coastal Geology and Geomorphology - A Synthesis, in: Treatise on Estuarine and Coastal Science, edited by: Wolanski, E. and McLusky, D. S., 3, 1-5, Waltham: Academic Press, 2011.

Kotti, F., Dezileau, L., Mahe, G., Habaieb, H., and Dieulin, C.: Reconstitution historique des apports sédimentaires par l'oued Medjerda, Tunisie, International Conference on African Large River Basins Hydrology, 26-30 October 2015, Hammamet, Tunisia, p. 41, 2015.

Milliman, J. D. and Meade, R. H.: World-Wide Delivery of River Sediment to the Oceans, J. Geol., 91, 1-21, doi.org/10.1086/628741, 1983.

Oueslati, A.: Littoral et aménagement en Tunisie, ORBIS presses, p. 534, 2004.

Perillo, G. M. E.: Geomorphology and sedimentology of estuaries, Developments in sedimentology, chap. 1, An Introduction, Vol. 53, 1-16. 1995.

Saïdi, H.: Etude sédimentologique et morphodynamique des côtes sableuses du golfe de Tunis (Tunisie nord-orientale), Thèse de doctorat, Faculté des Sciences de Tunis, 217 pp., 2013.

Saïdi, H., Souissi, R., Louati, M., and Zargouni, F.: Morphologic changes and sedimentary budgets along a Mediterranean coastline with a sand spit: case of the littoral fringe Sidi Ali El MekkiGammarth (NE Tunisia), Rend. Fis. Acc. Lincei, 25, 393-401, https://doi.org/10.1007/s12210-014-0314-0, 2014. 
Soussi, N.: Les mécanismes de la sédimentation dans le golfe de Tunis (Tunisie), condensés des travaux présentés lors du XXXIème congrès-Assemblée plénière, Athènes, Grèce, 92, 1988.

Suanez, S. and Sabatier, F.: Eléments de réflexion pour une gestion plus cohérente d'un système anthropisé: exemple du littoral du delta du Rhône/Ideas on the more coherent management of an anthropised system: the example of the coasts of the Rhône delta, In Revue de géographie de Lyon, Vol. 74, no. 1, Géographie des littoraux: la nature et les hommes, 7-25, https://doi.org/10.3406/geoca.1999.4925, 1999.
Syvitski, P. M. and Kettner, A.: Sediment flux and the Anthropocene, Philos. T. R. Soc. A, 369, 957-975, https://doi.org/10.1098/rsta.2010.0329, 2011. 